\title{
Olej ochronny o niskiej lepkości do czasowej ochrony elementów metalowych przed korozją
}

\section{Low viscosity protective oil for temporary protection of metal components against corrosion}

\author{
Monika Ziółkowska, Jarosław Frydrych \\ Sieć Badawcza Łukasiewicz - Przemysłowy Instytut Motoryzacji
}

\begin{abstract}
STRESZCZENIE: Korozja jest przyczyną niszczenia wielu metali pod wpływem oddziaływania czynników środowiskowych. Zachodzące na powierzchni metalu procesy chemiczne lub elektrochemiczne powodują nieodwracalne zmiany w strukturze metalu. Aby temu zapobiec, powierzchnie elementów metalowych muszą być zabezpieczane w czasie przechowywania lub transportu przed czynnikami środowiskowymi, do których zalicza się: dużą wilgotność powietrza, kwaśne opady i zmienną temperaturę. Te czynniki przyspieszają proces korozji, którego nie można wyeliminować, ale można go ograniczyć poprzez zabezpieczanie elementów metalowych, np. olejami ochronnymi. Niektóre metale mają zdolność pasywacji, będącej naturalnym środkiem ochronnym zapobiegającym korozji. Polega ona na wytworzeniu na powierzchni metalu tlenku tego metalu. Tam, gdzie nie ma naturalnej ochrony przed korozją, trzeba stosować środki ochronne. W artykule przedstawiono technologię produkcji oleju ochronnego do czasowej ochrony elementów metalowych przed korozją. Innowacją jest to, że olej na powierzchni metalu tworzy cienką, dobrze przylegającą warstwę ochronną, którą można łatwo usunąć. Charakteryzuje się niską lepkością i krótkim czasem ociekania. Jest to możliwe do osiągnięcia dzięki zastosowaniu właściwego oleju podstawowego i odpowiednio dobranych dodatków antykorozyjnych. Na podstawie normy PN-75/C-04154 Przetwory naftowe. Badanie własności przeciwkorozyjnych ciekłych środków ochrony czasowej metali w wilgotnej atmosferze wykonano badania korozyjne. Przedstawiono wyniki badań w komorze wilgotnościowej dla mieszanki olejowej opartej na oleju bazowym głęboko rafinowanym oraz odpowiednio dobranych dodatkach uszlachetniających. Wyniki badań potwierdziły bardzo dobre właściwości przeciwkorozyjne opracowanego oleju, uzyskane dzięki zastosowaniu inhibitora korozji oraz inhibitora utleniania. Na podstawie wzoru matematycznego obliczono grubość warstwy ochronnej wytworzonej na powierzchni metalu. Warstwa ta tworzy cienki film olejowy, łatwy do usunięcia i zabezpieczający powierzchnię metalu przed korozją.
\end{abstract}

Słowa kluczowe: korozja, olej ochronny, czasowa ochrona, lepkość, elementy metalowe, inhibitor korozji.

ABSTRACT: Corrosion of metals is the gradual destruction of metal under the impact of environmental factors. Chemical or electrochemical processes on the surface of the metal cause irreversible changes in the structure of the metal. To prevent this, during storage or transport, the surfaces of metal elements must be protected against environmental factors, which include: high air humidity, acid rain and variable temperature. These factors accelerate the corrosion process, which cannot be eliminated, but can be reduced by protecting metal elements with e.g. protective oils. Some metals have the ability to passivate, which is a natural protective agent that prevents corrosion. It consists in the formation of an oxide of this metal on the metal surface. Where there is no natural protection against corrosion, protective measures must be used. This paper presents the technology for the production of protective oil for temporary protection against corrosion. The innovation of this project is that the oil will form a thin, well adhering protective layer on the metal surface, which can be easily removed. It is characterised by very low viscosity and low dripping time. It is possible to achieve by using proper base oil with carefully selected anti-corrosion additives. Based on the standard PN-75/C-04154 Petroleum products. Rust protection by metal preservatives the humidity cabinet test method, corrosion tests were carried out. The paper presents the results of a humidity cabinet test for an oil mixture based on deeply refined base oil and properly selected refining additives. The test results confirmed very good anti-corrosive properties of the developed oil due to the use of a corrosion inhibitor and an oxidation inhibitor. The thickness of the protective layer formed on the metal surface was calculated based on a mathematical formula. The resulting layer forms a thin oil film, easy to remove and protecting the metal surface from corrosion.

Key words: corrosion, protective oil, temporary protection, viscosity, metal components, corrosion inhibitor.

Autor do korespondencji: M. Ziółkowska, e-mail: monika.ziolkowska@pimot.lukasiewicz.gov.pl

Artykuł nadesłano do Redakcji: 22.05.2020 r. Zatwierdzono do druku: 02.11.2020 r. 


\section{Wprowadzenie}

Korozja jest to proces stopniowego niszczenia metalu, który powoduje, że metal ze stanu wolnego przechodzi w stan chemicznie związany. Wobec tego korozja jest nieodwracalną reakcją materiału z otoczeniem (Surowska, 2002; Rudnick, 2009).

Korozja należy do zjawisk, których nie można całkowicie wyeliminować, ale można je znacznie ograniczyć.

Szczególny problem stanowi korozja wyrobów żeliwnych i stalowych. Skorodowane przedmioty tracą swoje właściwości użytkowe i muszą być zastąpione nowymi. Elementy konstrukcji budowlanych, części maszyn oraz inne wyroby wykonane z metali ulegają korozji ze względu na niestabilność metalu (Górecki, 1984; Gaździk et al., 2019). Od dawna wiadomo, że nie tylko czynniki środowiskowe powodują przyspieszanie procesów korozji, ale również jakość powierzchni, stopień przetworzenia metalu i jego skład chemiczny oraz warunki magazynowania (TOTAL, 2003).

Podczas produkcji wyrobów metalowych: łożysk, kół zębatych, przyrządów pomiarowych, narzędzi, części do pojazdów, broni i innych precyzyjnych części maszyn, blach kształtowników, szyn itp. powstaje problem ich ochrony czasowej przed korozją i rdzewieniem. Problem ten występuje również w przypadku transportu części metalowych (zwłaszcza drogą morską), a także podczas długotrwałego magazynowania, w szczególności w warunkach tropikalnych. Ochrona przed korozją musi być także zagwarantowana w sytuacjach, gdy wyroby metalowe są używane okresowo, a następnie długotrwale magazynowane.

Szczególnym przypadkiem ochrony metali przed korozją i rdzewieniem jest ochrona czasowa. Ochrona czasowa polega na konserwacji wyrobów metalowych łatwo usuwalnymi lub niewymagającymi usuwania środkami konserwacyjnymi oraz na pakowaniu ochronnym.

Najłatwiejsze do usunięcia są filmy przeciwkorozyjne, stosowane jako tymczasowe lub krótkotrwałe pokrycia.

Niektóre metale mają zdolność wytwarzania na swojej powierzchni warstewki ochronnej w postaci tlenku. Zjawisko to nosi nazwę pasywacji. Pasywacja niektórych metali jest naturalnym środkiem ochronnym zapobiegającym korozji. Tlenki metali na wyższym stopniu utlenienia są mniej rozpuszczalne od tlenków na niższym stopniu utlenienia i dlatego ulegają pasywacji w wyniku utleniania oraz aktywacji w wyniku redukcji. Do tej grupy metali należą (w kolejności malejącej skłonności do pasywacji): tytan, chrom, cyna, żelazo, mangan, ołów, srebro, nikiel, kobalt (Surowska, 2002).

Korozja powstaje wówczas, kiedy metal zostanie wystawiony na działanie czynników środowiskowych powietrza i nie ma zdolności do pasywacji. Metalem, który łatwo ulega pasywacji, jest chrom. Po zetknięciu z tlenem atmosferycznym na powierzchni chromu wytwarza się warstewka tlenku chromu(III), trwałego tlenku, dzięki któremu proces korozji zostaje zahamowany. Dlatego elementy metalowe bardzo często są chromowane, co stanowi naturalny środek ochrony przeciwkorozyjnej. Po pewnym czasie ta warstewka tlenku może zostać uszkodzona i wówczas następuje depasywacja. W miejscu, gdzie doszło do uszkodzenia naturalnej warstwy ochronnej, może rozpocząć się proces korozji. Jednak chrom ma zdolność do odbudowy tej warstwy, tzn. zachodzi proces repasywacji, czyli odbudowy uszkodzonej warstwy pasywującej.

\section{Środki ochrony czasowej}

Środki czasowej ochrony przed korozją są to substancje nakładane na powierzchnie metalowe lub na powłoki ochronne niemetaliczne tworzące na powierzchni łatwo usuwalne lub niewymagające usuwania warstewki, chroniące metal przed korozją w określonym środowisku i przez ograniczony czas.

Jako środki ochrony czasowej metali przed korozją najczęściej stosowane są:

- oleje mineralne z odpowiednim pakietem dodatków uszlachetniających, tzw. oleje konserwujące;

- oleje konserwujące z rozpuszczalnikiem;

- smary konserwujące;

- smary konserwujące z rozpuszczalnikiem;

- roztwory wosków lub lanoliny z pakietem dodatków;

- substancje syntetyczne tworzące cienki lub ultracienki film, które są przeważnie specjalnym inhibitorem korozji rozprowadzonym w odpowiednim rozpuszczalniku;

- wodne emulsje zawierające środek konserwujący.

Środki ochrony czasowej, oprócz składników podstawowych, a w określonych przypadkach rozpuszczalnika, zawierają dodatki: inhibitory korozji, inhibitory utleniania, substancje zwilżające, barwniki, a w przypadku smarów konserwujących także zagęszczacze.

Ciecze zapobiegające rdzewieniu lub korozji zestawione są na bazie lekkich olejów z dodatkiem inhibitorów korozji, środków wytwarzających na powierzchni cienką warstwę filmu ochronnego lub na bazie rozpuszczalników, olejów i wody, tj. emulsji wodno-olejowej.

O właściwościach ochronnych decydują inhibitory korozji. Inhibitory nieorganiczne i organiczne to dwa główne rodzaje dodatków opóźniających procesy korozji. Inhibitory nieorganiczne, takie jak: azotyny, azotany, chromiany, dichromiany i fosforany, są szeroko stosowane w różnych olejach bazowych. Natomiast organicznymi inhibitorami są związki zawierające jedną lub więcej grup polarnych (z atomami O, N, P, S i elektrony $\pi$ ), które skutecznie zapobiegają korozji poprzez adsorpcję na metalowej powierzchni (McGuire, 2016; Tang, 2019). 
W praktyce rozróżnia się następujące typy środków ochrony czasowej:

- przeciwkorozyjne niezawierające rozpuszczalników (typ 1);

- przeciwkorozyjne zawierające rozpuszczalniki (typ 2);

- przeciwkorozyjne mieszające się z wodą lub tworzące z nią emulsje (typ 3).

Środki ochrony czasowej przed korozją typu 1 są to tak zwane konserwacyjne (przeciwkorozyjne) oleje ochronne, w skład których wchodzą oleje mineralne lub syntetyczne i inhibitory korozji. W zależności od wprowadzonych dodatków, lepkości olejów użytych jako bazy oraz rodzaju wykorzystanych inhibitorów korozji - tworzą cienki film olejowy o różnej trwałości. Stosowane są do długoterminowej konserwacji wewnętrznych powierzchni bardzo małych części, małych jednostek maszynowych, hydrauliki, części napędów itd. Konserwowane elementy metalowe powinny być zapakowane lub przykryte podczas składowania w zamkniętych pomieszczeniach (TOTAL, 2003).

Specjalną odmianą środków ochrony czasowej są oleje ochronne z zawartością lotnych inhibitorów korozji, rodzaju VCI (ang. volatile corrosion inhibitor), zwanych inhibitorami w fazie gazowej. Inhibitory te powodują dodatkowe tworzenie na powierzchniach metalu związków kompleksowych.

Do kolejnej grupy środków ochrony przed korozją zalicza się oleje mineralne tworzące z wodą emulsje. Do tego typu olejów wprowadzany jest dodatek - emulgator, którego zadaniem jest wytworzenie emulsji po zetknięciu się z wodą. Taka emulsja nanoszona jest na powierzchnię metalu (Darowicki, 2007).

\section{Badanie właściwości przeciwkorozyjnych}

W celu wykonania badań właściwości przeciwkorozyjnych i oceny środka smarowego należy najpierw nanieść go na powierzchnię metalu. W zależności od kształtu i wielkości zabezpieczanej powierzchni należy wybrać taką metodę, która zapewni całkowite pokrycie, nawet $\mathrm{w}$ miejscach mało dostępnych.

Przed nałożeniem powłoki środka ochrony czasowej powierzchnia metalu musi zostać starannie oczyszczona z wszelkich ciał obcych, wilgoci, zanieczyszczeń mechanicznych, resztek soli, olejów i smarów - od tego zabiegu zależy w znacznym stopniu uzyskany efekt ochronny. Oczyszczanie powierzchni wyrobów odbywa się poprzez mycie lub płukanie przy użyciu rozpuszczalników, odtłuszczanie w kąpielach alkalicznych lub specjalnych płynach (Gaździk et al., 2019). Istnieje wiele metod nanoszenia środka smarowego na chronioną powierzchnię, np. zanurzenie elementu, natrysk na powierzchnię lub malowanie pędzlem (smarowanie), ale najbardziej rozpowszechnioną i najczęściej stosowaną jest metoda zanurzeniowa. Metoda zanurzeniowa polega na zanurzeniu elementu w ciekłym środku przeciwkorozyjnym, następnie wyjęciu go z niego i poddaniu procesowi usuwania nadmiaru środka poprzez: obcieknięcie, odwirowanie i odparowanie rozpuszczalnika. Po zakończeniu tych procesów element metalowy pozostawia się do ostygnięcia. Metodę zanurzeniową stosuje się do czasowej ochrony elementów metalowych o niewielkich rozmiarach. Czas zanurzenia wynosi od 2 do $10 \mathrm{mi}-$ nut, w zależności od wielkości i kształtu części oraz właściwości środka przeciwkorozyjnego. Zaleca się, aby konserwowane elementy nie stykały się ze sobą.

Metoda zanurzeniowa jest bardzo dobrym sposobem konserwacji. Środek ochronny wnika do wszystkich otwartych części zabezpieczanego metalu, pokrywając go w miarę równomiernie.

Metoda na zimno jest stosowana w przypadku konieczności ochrony międzyoperacyjnej i krótkotrwałej. Jako środki przeciwkorozyjne stosowane są oleje o niskiej lepkości lub środki ochrony czasowej zawierające rozpuszczalnik. W zależności od lotności rozpuszczalnika jego odparowanie trwa od 3 do 20 minut. Pary rozpuszczalnika są odprowadzane poprzez wyciąg, skraplane i zawracane do procesu.

Metoda zanurzeniowa jest najczęściej stosowana w przypadku nakładania środków dających warstwę cienką lub ultracienką.

Metoda badania właściwości przeciwkorozyjnych dla oleju ochronnego w komorze wilgotnościowej została opracowana na podstawie normy PN-75/C-04154 Badanie wtasności przeciwkorozyjnych cieklych środków ochrony czasowej metali $w$ wilgotnej atmosferze. Badanie polegało na umieszczeniu stalowych płytek pokrytych badanym olejem w komorze wilgotnościowej w temperaturze $50^{\circ} \mathrm{C}$, a następnie stwierdzeniu, po upływie określonego czasu, zmian powstałych na powierzchni płytek.

Wypolerowane płytki stalowe o wymiarach $50 \times 120 \mathrm{~mm}$ pokryto olejem ochronnym i umieszczono w komorze wilgotnościowej wypełnionej wodą. Płytki w komorze zamocowano za pomocą haczyków. Badanie prowadzono w temperaturze $50 \pm 2{ }^{\circ} \mathrm{C}$ i stałej wilgotności $90-100 \%$. Przez komorę przepuszczano powietrze, które zapewniło cyrkulację wody i odpowiednią wilgotność, a ponadto było czynnikiem utleniającym. W tych warunkach płytki przetrzymywano do pierwszych śladów korozji, ale nie dłużej niż do pojawienia się 3 punktów korozyjnych o średnicy nie większej niż $1 \mathrm{~mm}$. Czas badania w komorze wilgotnościowej określa się za pomocą cykli. Jeden cykl to 24 godziny przetrzymywania badanej płytki w komorze w temperaturze $50 \pm 2{ }^{\circ} \mathrm{C}$ i wilgotności $90-100 \%$. Po każdym cyklu prowadzono obserwację płytek i oceniano płytki pod kątem śladów korozji.

Na rysunkach 1 i 2 przedstawiono komorę wilgotnościową, w której prowadzone były badania. 


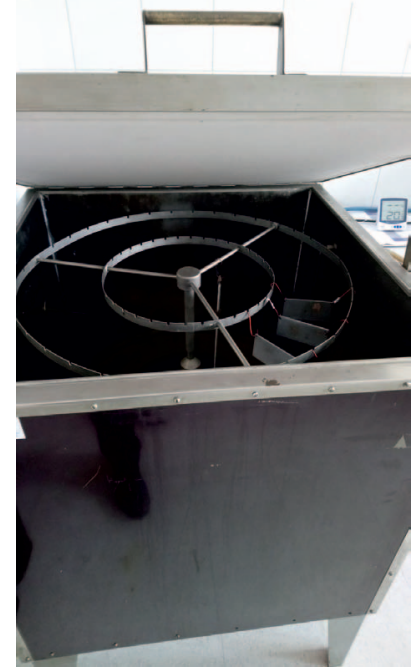

Rys. 1. Widok komory wilgotnościowej

Fig. 1. View of the humidity cabinet

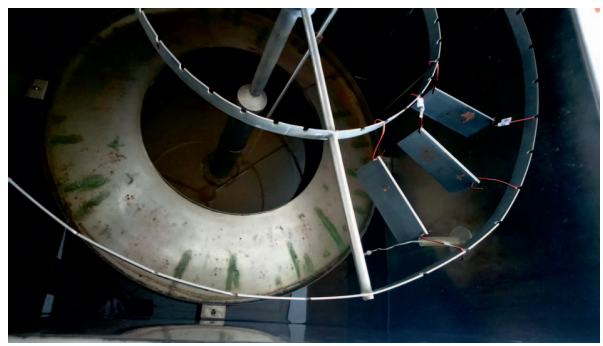

Rys. 2. Wnętrze komory wilgotnościowej z umieszczonymi płytkami Fig. 2. The interior of the humidity cabinet with the plates placed
Tabela 1. Badanie właściwości przeciwkorozyjnych mieszanek olejowych

Table 1. Testing anticorrosive properties of oil mixtures

\begin{tabular}{|c|c|}
\hline Mieszanki olejowe & $\begin{array}{c}\text { Badanie wlaściwości } \\
\text { przeciwkorozyjnych } \\
\text { womorze wilgotnościowej }\end{array}$ \\
\hline \hline WZORZEC - płytka niepokryta olejem & 1 cykl \\
\hline MIESZANKA nr 1 & 5 cykli \\
\hline MIESZANKA nr 2 & 7 cykli \\
\hline MIESZANKA nr 3 & 5 cykli \\
\hline MIESZANKA nr 4 & 4 cykle \\
\hline MIESZANKA nr 5 & 1 cykl \\
\hline
\end{tabular}

$1 \mathrm{cykl}=24$ godziny

Na rysunkach 3-8 przedstawione zostały zdjęcia płytek po badaniu w komorze wilgotnościowej dla wybranych mieszanek.

Powyższe badania pozwoliły na wytypowanie mieszanki nr 2 jako wstępnej receptury oleju ochronnego. Następnie ponownie wykonano badania właściwości przeciwkorozyjnych.

Przed przystąpieniem do badań płytkę stalową bardzo dokładnie oczyszczono i wypolerowano, aby na powierzchni nie pozostawały żadne zagłębienia ani bruzdy, gdyż może to prowadzić do niedokładnego pokrycia płytki, a tym samym mieć wpływ na właściwości ochronne.
Badaniu właściwości przeciwkorozyjnych w komorze wilgotnościowej zostały poddane mieszanki olejowe $-\mathrm{w}$ celu wybrania optymalnej receptury oleju ochronnego. Mieszanki zostały zestawione na bazie oleju o wysokim stopniu czystości oraz pakietu dodatków uszlachetniających i dodatkowo wzbogacone dodatkiem antykorozyjnym. Mieszanki różniły się między sobą ilością pakietu dodatków uszlachetniających i dodatku antykorozyjnego.

Za koniec badania przyjęto pierwsze ślady korozji, maksymalnie 3 punkty o średnicy do $1 \mathrm{~mm}$.

Wstępne badania w komorze wilgotnościowej pozwolily na wytypowanie mieszanek olejowych, które charakteryzowały się najlepszymi właściwościami ochronnymi, mieszanki te ponownie poddano badaniu. Płytki stalowe, tak jak poprzednio, zostały pokryte mieszankami olejowymi metodą zanurzeniową, a następnie umieszczone w komorze wilgotnościowej. Wyniki badań przeciwkorozyjnych mieszanek olejowych przedstawiono w tabeli 1 .

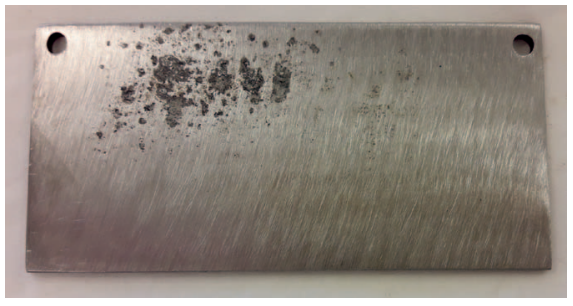

Rys. 3. Mieszanka nr 1

Fig. 3. The mixture no. 1

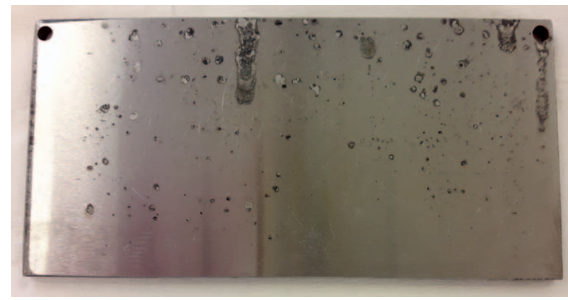

Rys. 5. Mieszanka nr 3

Fig. 5. The mixture no. 3

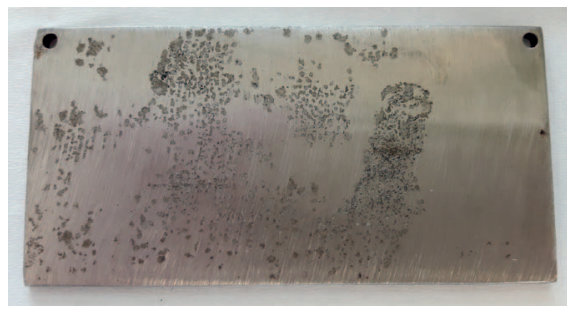

Rys. 7. Mieszanka nr 5

Fig. 7. The mixture no. 5

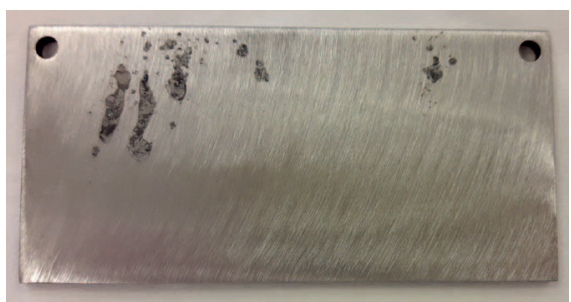

Rys. 4. Mieszanka nr 2

Fig. 4. The mixture no. 2

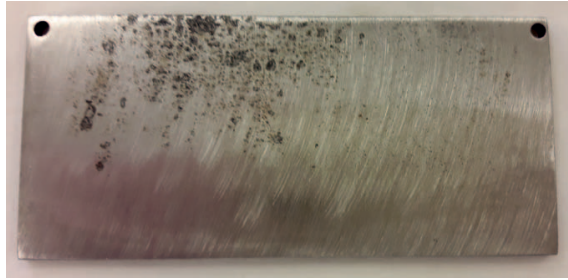

Rys. 6. Mieszanka nr 4

Fig. 6. The mixture no. 4

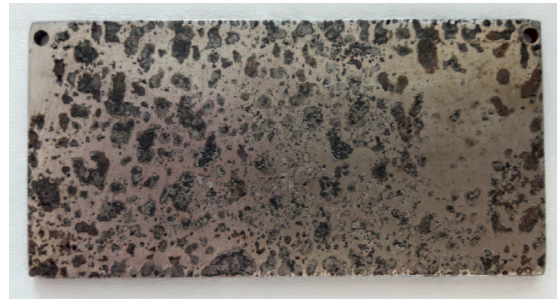

Rys. 8. Wzorzec

Fig. 8. The pattern 
Dla mieszanki olejowej nr 2 powtórzono wynik badania właściwości fizykochemicznych, który przedstawiono w tabeli 2. Natomiast na rysunku 9 przedstawiono płytkę pokrytą mieszanką olejową nr 2 po badaniu w komorze wilgotnościowej.

Dla wyżej wymienionej mieszanki obliczono metodą wagową grubość warstwy ochronnej wytworzonej na powierzchni

Tabela 2. Wynik badania właściwości fizykochemicznych

Table 2. Result of the physicochemical properties test

\begin{tabular}{|c|c|}
\hline Mieszanka olejowa & $\begin{array}{c}\text { Badanie wlaściwości przeciwkoro- } \\
\text { zyjnych w komorze wilgotnościowej }\end{array}$ \\
\hline \hline MIESZANKA nr 2 & 14 cykli \\
\hline
\end{tabular}

$1 \mathrm{cykl}=24$ godziny

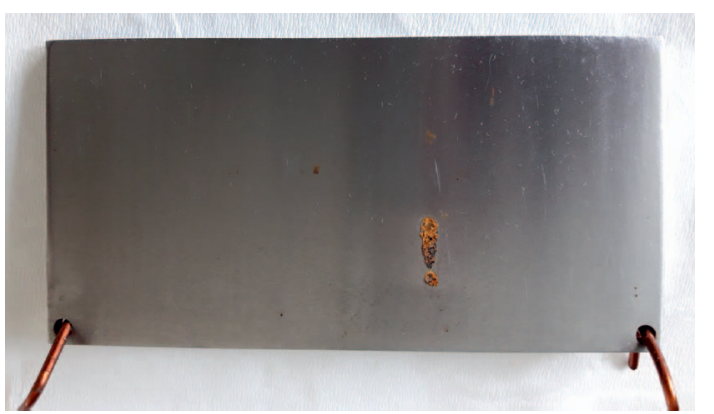

Rys. 9. Płytka stalowa pokryta mieszanką olejową $\mathrm{nr} 2$

Fig. 9. Steel plate covered with the oil mixture no. 2 płytki stalowej. Grubość warstwy ochronnej ( $D-$ w mikrometrach) utworzonej przez środek ochrony czasowej wyznaczono ze wzoru:

$$
D=10000 \cdot\left(M_{2}-M_{1}\right) / \rho \cdot A
$$

gdzie:

$M_{2}$ - masa płytki stalowej z naniesionym środkiem ochrony czasowej [g],

$M_{1}$ - masa czystej płytki przed naniesieniem środka ochronnego [g],

$\rho$ - gęstość środka ochrony czasowej $\left[\mathrm{g} / \mathrm{cm}^{3}\right]$,

$A$ - całkowita powierzchnia płytki testowej $\left[\mathrm{cm}^{2}\right]$.

\section{Olej ochronny o niskiej lepkości}

Olej ochronny o niskiej lepkości został opracowany na bazie oleju bazowego, który otrzymywany jest z ropy naftowej metodą wielokrotnej głębokiej rafinacji. Głęboka rafinacja zapewnia otrzymanie oleju o wysokim stopniu czystości i bardzo niskiej lepkości. Właściwości użytkowe, w tym przypadku właściwości ochronne, nadaje olejowi odpowiednio dobrany pakiet dodatków uszlachetniających, który został wzbogacony dodatkiem przeciwkorozyjnym. Tak skomponowany olej ochronny spełnił wymagania właściwości

Tabela 3. Wyniki badań właściwości fizykochemicznych oleju ochronnego

Table 3. Results of the test physicochemical properties of the protective oil

\begin{tabular}{|c|c|c|}
\hline Badane parametry & Jednostka miary & Olej ochronny \\
\hline $\begin{array}{l}\text { Lepkość kinematyczna } \\
\text { - w temperaturze } 40^{\circ} \mathrm{C} \\
\text { - w temperaturze } 100^{\circ} \mathrm{C}\end{array}$ & $\mathrm{mm}^{2} / \mathrm{s}$ & $\begin{array}{l}8,415 \\
2,437\end{array}$ \\
\hline Wskaźnik lepkości & - & 111 \\
\hline Temperatura płynięcia & ${ }^{\circ} \mathrm{C}$ & -15 \\
\hline Temperatura zapłonu & ${ }^{\circ} \mathrm{C}$ & 168 \\
\hline Odczyn wyciągu wodnego & - & alkaliczny \\
\hline Badanie działania korodującego na płytkach z $\mathrm{Cu}, 100^{\circ} \mathrm{C} / 3 \mathrm{~h}$ & skala ASTM & bez zmian \\
\hline Pozostałość po spopieleniu & $\%(m / m)$ & 0,01 \\
\hline Badanie własności przeciwkorozyjnych na trzpieniu stalowym & - & brak korozji \\
\hline Zawartość stałych ciał obcych & $\%$ & nie zawiera \\
\hline Zawartość wody & $\%$ & nie zawiera \\
\hline Gęstość w temperaturze $20^{\circ} \mathrm{C}$ & $\mathrm{kg} / \mathrm{dm}^{3}$ & 0,885 \\
\hline Barwa wg Lovibonda & - & 3,0 \\
\hline $\begin{array}{l}\text { Badanie własności smarnych na aparacie 4-kulowym } \\
\text { - obciążenie zespawania, } P_{z}\end{array}$ & $\mathrm{kG}$ & 160 \\
\hline $\begin{array}{l}\text { Test przeciwzużyciowy } \\
\text { - średnia średnica skazy kulek w ciągu } 60 \text { min pod obciążeniem } 40 \mathrm{kG}, \mathrm{d}_{40 / 60}\end{array}$ & $\mathrm{~mm}$ & 0,42 \\
\hline Grubość warstwy wytworzonej przez środek ochronny & $\mu \mathrm{m}$ & 5 \\
\hline Badanie własności przeciwkorozyjnych w komorze wilgotnościowej & liczba cykli* & 14 \\
\hline
\end{tabular}

* $1 \mathrm{cykl}=24$ godziny 
przeciwkorozyjnych oraz pozostałe wymagania stawiane olejom ochronnym.

Powyższa receptura oleju ochronnego o niskiej lepkości jest modyfikacją receptur oleju ochronnego i oleju hydrauliczno-ochronnego, których skład i receptura objęte są patentami (Patent PL 195208, 2001; Patent PL 201820, 2003).

W tabeli 3 zamieszczono wyniki badań właściwości fizykochemicznych opracowanego oleju ochronnego o niskiej lepkości.

Bardzo dobre właściwości antykorozyjne zagwarantowane są dzięki inhibitorowi korozji i inhibitorowi utleniania. $Z$ chemicznego punktu widzenia inhibitorem korozji jest kwas alkilokarboksylowy, natomiast inhibitorem utleniania - alkilofenol.

To dzięki tym związkom olej ochronny tworzy na powierzchni metalu bardzo cienką, dobrze przylegającą do całej powierzchni, jednorodną i trwałą warstwę, a także charakteryzuje się niską lepkością, niskim napięciem powierzchniowym i dobrymi właściwościami smarnymi.

\section{Wnioski}

Na podstawie przeprowadzonych badań można stwierdzić, że:

1) olej ochronny przeznaczony do ochrony czasowej elementów metalowych składający się z oleju bazowego głęboko rafinowanego, pakietu dodatków uszlachetniających oraz dodatku przeciwkorozyjnego spełnił wymagania w zakresie właściwości lepkościowych i ochronnych;

2) opracowany olej charakteryzuje się:

- niską lepkością kinematyczną,

- krótkim czasem ociekania,

- cienką, niebrudzącą warstwą oleju pozostawianą na powierzchni metalu,

- bardzo dobrymi właściwościami ochronnymi,

- dobrymi właściwościami smarnymi;

3) badania stanowiskowe przeprowadzone w Sieci Badawczej Łukasiewicz - Przemysłowym Instytucie Motoryzacji zakończyły się wynikiem pozytywnym. Na zabezpieczonych powierzchniach nie zaobserwowano śladów korozji ani zmiany barwy, co świadczy o bardzo dobrych właściwościach ochronnych nowo opracowanego oleju.

\section{Literatura}

Darowicki K. (red.), 2007. Procesy korozyjne. Monografia. Politechnika Gdańska, Katedra Elektrochemii, Korozji i Inżynierii Materiałowej.

Gaździk B., Kempiński R., Paćkowski Z., Pomykała K., 2019. Innowacyjne środki myjąco-konserwujące i oleje ochronne. Nafta-Gaz, 7: 430-444. DOI: 10.18668/NG.2019.07.07.

Górecki A., 1984. Technologia ogólna. Podstawy technologii mechanicznych. WSiP, Warszawa.

McGuire N., 2016. Fundamentals of rust preventives used for temporary corrosion protection. Tribol. Lubric. Technol., 72(9): 28-34.

Rudnick L.R., 2009. Lubricant Additives: Chemistry and Applications. Second ed. CRC Press.

Surowska B., 2002. Wybrane zagadnienie z korozji i ochrony przed korozją. Podręcznik dla studentów. Politechnika Lubelska, Wydziat Mechaniczny, Lublin. ISBN 83-88110-54-3.

Tang Z., 2019. A review of corrosion inhibitors for rust preventative fluids. Current Opinion in Solid State and Materials Science, 23(4): 100759.

TOTAL, 2003. Czasowa ochrona metali przed korozją. [W:] Przemysłowe środki smarne. Poradnik. Warszawa.

\section{Akty normatywne i patenty}

PN-75/C-04154 Badanie własności przeciwkorozyjnych ciekłych środków ochrony czasowej metali w wilgotnej atmosferze.

Patent nr PL 195208 B1 Olej ochronny, 2001.

Patent nr PL 201820 B1 Olej przekładniowo-ochronny i hydrauliczno-ochronny, 2003.

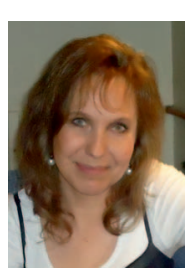

Mgr Monika ZIÓŁKOWSKA

Starszy specjalista

Sieć Badawcza Łukasiewicz - Przemysłowy Instytut Motoryzacji

ul. Jagiellońska 55

03-301 Warszawa

E-mail:monika.ziolkowska@pimot.lukasiewicz.gov.pl

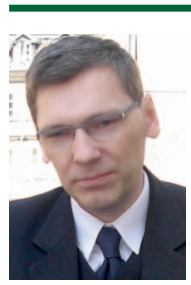

Mgr Jarosław FRYDRYCH

Starszy specjalista

Sieć Badawcza Łukasiewicz - Przemysłowy Instytut Motoryzacji

ul. Jagiellońska 55

03-301 Warszawa

E-mail: jaroslaw.frydrych@pimot.lukasiewicz.gov.pl 